\title{
Investment Portfolio Strategies Based On Options Market Activity
}

Rafiqul Bhuyan, California State University, San Bernardino, USA

Steven Freund, University of Massachusetts, Lowell, USA

Yuxing Yan, University of Pennsylvania, Philadelphia, USA

\begin{abstract}
We propose a multiple regression model that incorporates options market activity to forecast future stock prices. To capture the information content from the options market, we use a predictor based on the activity of call and put options as measured by relative open interest across available strike prices. We use a sample of stocks with actively traded options on the Chicago Board Options Exchange to test the model. Investment strategies that use these forecasts are shown to be superior to more simple strategies which ignore options market activity.
\end{abstract}

Keywords: Options, Open Interest, Trading Strategies.

\section{INTRODUCTION}

Equity options markets are regarded by many academicians and practitioners as attractive markets for informed traders. Trading activity in these markets may reflect information that has not yet been incorporated into the underlying stock price and might possibly improve the prediction of future price movements of the underlying security. The purpose of our research is to investigate the benefits of using options market activity for designing investment strategies.

We utilize relative open interest over all available put and call strike prices to generate a price predictor which we then use, along with the contemporaneous stock price, to forecast the underlying stock price for the option expiration day. We obtain coefficients for our forecast model using thirty stocks over a three month period and use the resulting coefficients in the following three month period to forecast the stock price at option maturity. The objective is to test if investors can generate superior trading gains by selecting appropriate trading strategies to take advantage of open interest data in the options market.

We compare the returns of two types of investors: Informed investors who have access to the forecasts based on information from the options market, and uninformed investors who do not. In our first test, the uninformed investors always take long positions in the stock, while informed traders use the price forecast to decide between a long and a short position. Our second test allows for the use of options as well as the underlying stock in the investment portfolio. The uninformed investors use a covered call strategy using the nearest out-of-the-money strike price while informed investors use the price forecast to select the strike price for the covered call. In addition, if the forecast is lower than the contemporaneous stock price, informed investors also add a purchased put to the covered call.

All the strategies, irrespective of their reliance on open interest information, outperform the S\&P 500 Index. The strategies used by the informed investors, based on options market activity, result in mean returns that are higher than the returns for the strategies used by the uninformed investors that ignore options marked activity. The best performing strategies for the informed investors not only use the options market information but also use options as part of the strategy. 


\section{LITERATURE REVIEW}

The information content of derivatives has been a subject of researchers since the onset of trading on the Chicago Board Options Exchange and the subsequent publication of first successful option pricing model by Black and Scholes [3]. Chiras and Manaster [5] find that different strike prices and maturities of options on the same stock result in different implied standard deviations for the stock. Manaster and Rendleman [7] use daily closing option prices as predictors of the equilibrium stock prices. The comparison reveals that the implied prices contain information regarding equilibrium stock prices that are not fully reflected in observed stock prices.

Anthony [1] investigates the relation between common stocks and call options trading volumes. Using daily closing data, he finds that option volume leads trading in common stock. Blume, Easley, and O'Hara [4] emphasize the vital role of transaction volume as a statistic for technical analysis. Easley, O'Hara, and Srinivas [6] find that some option volume has predictive power of the underlying stock return.

Volume and open interest are different measures of trading activity. For every purchase and accompanying sale of a single call or put contract, volume for the day increases. But whether there is an equivalent increase in open interest depends on the previous trading history of both seller and buyer. If both the buyer and seller are initiating new positions, open interest will increase. If both buyer and seller are closing out previous positions, open interest will decrease. It is also possible that open interest will remain unchanged if one side is opening a new position while the other side closes out a previously held position. In general, open interest builds up from the point that new option contracts become available and decreases as the option maturity draws near; it is cheaper to offset contracts with opposite positions rather than go through with an exercise at expiration.

Table 1: Sample Stocks

\begin{tabular}{|c|c|}
\hline Firm Name & Ticker Symbol \\
\hline Barrick Gold Corp. & $\mathrm{ABX}$ \\
\hline Altera Corp. & ALTR \\
\hline Applied Materials & AMAT \\
\hline Amgen, Inc. & AMGN \\
\hline American Airlines, Inc. & AMR \\
\hline Ascend Communications & ASND \\
\hline Citigroup Inc. & $\mathrm{C}$ \\
\hline Chase Manhattan Corp. & CMB \\
\hline 3Com Corporation & COMS \\
\hline Compaq Computer Corp. & CPQ \\
\hline Cisco Systems, Inc. & $\mathrm{CSCO}$ \\
\hline Century Telecommunications Inc & CTL \\
\hline Delta Airlines, Inc. & DAL \\
\hline E.I. DuPont De Nemours & DD \\
\hline Dell Computer Corporation & DELL \\
\hline Walt Disney Company & DIS \\
\hline General Electric Company & GE \\
\hline Coca-Cola Company & $\mathrm{KO}$ \\
\hline McDonald's Corporation & MCD \\
\hline Philip Morris Companies & MO \\
\hline Motorola, Inc. & MOT \\
\hline Micron Technology, Inc. & MU \\
\hline Oracle Corporation & ORCL \\
\hline Proctor and Gamble Co. & PG \\
\hline Sears, Inc. & $\mathrm{S}$ \\
\hline Schlumberger Limited & SLB \\
\hline Sun Micro Systems Inc. & SUNW \\
\hline United Technologies & UTX \\
\hline MCI WorldCom, Inc. & WCOM \\
\hline Wall-Mart Stores, Inc. & WMT \\
\hline
\end{tabular}




\section{DATA AND FORECASTING MODEL}

The data are obtained from the Dreyfus Brokerage Services' Options Data Base which is derived from the Market Data Report of the Chicago Board of Options Exchange (CBOE). Table 1 shows the firm names and ticker symbols of our sample of thirty actively traded firms which trade options on the CBOE over six consecutive months from February through July of 1999. We use options data for the first three months to conduct regression analysis to verify if a price predictor based on open interest data can explain the movements of the underlying stock price in the presence of contemporaneous security prices. Options data for the next three months is then used to forecast the exante stock price.

Suppose that on day $t$, for a given stock with price $P_{t}$, there is available for trading $K$ possible strike prices for calls and $L$ possible strike prices for puts, all with common expiration day $T$. For the calls, we denote $O_{i t}{ }^{C}$ as the open interest for strike price $X_{i .}{ }^{C}$. For the puts, we denote $O_{i t}{ }^{P}$ as the open interest for strike price $X_{i}^{P}$. We define our price predictor $P_{t}^{Z}$ from the options market as:

$$
P_{t}^{Z}=\frac{\sum_{i=1}^{K} O_{i t}^{C} X_{i}^{C}+\sum_{i=1}^{L} O_{i t}^{P} X_{i}^{P}}{\sum_{i=1}^{K} O_{i t}^{C}+\sum_{i=1}^{L} O_{i t}^{P}}
$$

The price predictor is a weighted average of all available strike prices for both puts and calls, and the weights are the proportion of open interest associated with that particular strike price, relative to the total open interest for all options with common expiration day $T$. This price predictor is directly utilized for investment strategies in Bhuyan and Chaudhury [2], with favorable results.

Consider an investor having positive information regarding the stock price. He may be inclined to use the options market for reduced trading costs or increased leverage. If he is truly informed, he is likely to buy deep outof-the-money options. The greater his optimism, the more willing he is to purchase a higher strike price call. Another strategy would be to sell in-the-money puts. Again, increased optimism or knowledge about high stock price at expiration should favor the use of a higher strike price for selling puts. This is the intuition behind using the weighted average of the strike prices with relative open interest being the weights.

We design a multiple regression model for forecasting the stock price at expiration, using both the predictor $P_{t}^{Z}$, and the contemporaneous stock price $P_{t}$ :

$P_{j T m}=a_{0 m}+a_{1 m} P_{j t m}^{Z}+a_{2 m} P_{j t m}+\varepsilon_{j t m}$

Subscript " $j$ " denotes the cross section of firms, $j=1,2,3, \ldots . ., 30$; the subscript " $m$ " denotes the time series dimension, " $m$ " = February, March, or April. The disturbance term $\varepsilon_{j t m}$ has the following error structure:

$\varepsilon_{j t m}=\mu_{j t}+\eta_{j t m}$

This formulation is the simplest way of capturing the notion that two observations from the same individual firm will have a firm specific effect as well as other stochastic effects that are not captured by the specification of the model. Both errors on the right hand side of have zero means. We estimate the regression equation using the General Method of Moments for day $T-21$ where $T$ is the option maturity date. Table 2 shows the coefficients obtained for each month. The Newey-West [7] chi-square test does not reject the hypothesis that $a_{0,}, a_{1}$ and $a_{2}$ are the same for each month. Identical coefficients for all three months are shown in the last column. 
Table 2: Coefficient Estimates For Forecasting The Stock Price

\begin{tabular}{cl|c|c|c|c}
\hline \multicolumn{2}{c|}{ Explanatory Variables } & $\begin{array}{c}\text { Coefficients } \\
\text { February }\end{array}$ & March & April & Identical Coefficients Each Month \\
\hline \multirow{2}{*}{ Intercept: } & Coefficient & -3.769 & -0.684 & -4.133 & -3.672 \\
& Std. Error & 2.819 & 5.246 & 2.144 & 1.801 \\
$P_{t m}{ }^{Z}$ & Coefficient & 0.230 & -0.208 & 0.545 & $0.383^{*}$ \\
& Std. Error & 0.140 & 0.311 & 0.104 & 0.076 \\
$P_{t m}$ & Coefficient & 0.819 & 1.209 & 0.535 & $0.672^{*}$ \\
& Std. Error & 0.124 & 0.271 & 0.087 & 0.066 \\
\hline
\end{tabular}

*Statistically significant at the 0.01 level.

\section{TRADING STRATEGY}

We consider two types of investors: Informed investors who generate the option-based price predictors and uninformed investors who do not. Our first strategy has informed investors going long or short based on the forecast, while uninformed investors only go long. A second strategy allows for the use of options by both investor types. Merton, Scholes, and Gladstein [5] show that investors can improve a stock only strategy through the use of covered call writing. The use of covered calls will reduce risk exposure. Another advantage for using options is the possibility of a restriction on short sales due to limited availability of shares.

For our second strategy, uninformed investors write covered calls, using the closest out-of-the-money strike price to the contemporaneous stock price. Informed investors consider the forecast price based on open interest. When the forecast is above the contemporaneous price, they also write covered calls, but pick the out-of-the-money strike price closest to the forecast price. When the forecast price is below the contemporaneous price, they again write a covered call with a strike price closest to the forecast price and also add a purchased put with a strike price closest to the contemporaneous price. For this last case, no consideration is made to the moneyness of either options.

For the informed investor, the use of the forecast price to select the strike price for the covered call will increase the return if the forecast turns out to be accurate. The addition of a purchased put for a forecasted market downturn turns the covered call into a bear spread, which has a higher payoff should the forecast turn out to be accurate. Informed traders use the forecasted price $P_{t i}^{f}$ from equation 2, using the estimated coefficients given by Table 2, when the coefficients are restricted to be identical across months. The strategies for both informed and uninformed traders are:

Stock Only Strategy: Uninformed: $\quad$ Purchase the security $i$ at price $P_{t i}$.

Informed: $\quad$ If $P_{t i}^{f}>P_{t i}$, purchase security $i$ at price $P_{t i}$.

If $P_{t i}^{f}<P_{t i}$, sell security $i$ short at price $P_{t i}$.

Stock with Options Strategy: Uninformed: $\quad$ Purchase the security $i$ at price $P_{t i}$, and sell an out-of-themoney call option with strike price nearest to price $P_{t i}$.

Informed: $\quad$ If $P_{t i}^{f}>P_{t i}$, purchase security $i$ at price $P_{t i}$ and sell an out-ofthe-money option with strike price nearest to $P_{t i}^{f}$.

If $P_{t i}^{f}<P_{t i}$, purchase security $i$ at price $P_{t i}$, sell a call option with strike price nearest to $P_{t i}^{f}$, and purchase a put option with strike price nearest to price $P_{t i}$.

We allow the open interest to accumulate during the option month. Since open interest is a cumulative measure, it will reflect investors' revised expectations, which will make the inference of future stock price more 
informative. Investors are assumed to make their portfolio decisions three weeks prior to the expiration day of each month (day $\mathrm{T}-21$ ) with the intention to close out their positions on the expiration day of the option.

We do not consider the transaction costs on stocks, because the transaction fees on trading stocks is very low. Also, since we compare the performance of our trading strategy using the same stock for both investor types, transaction costs would be similar. Informed investors may trade greater amount of options, therefore we do consider the transaction cost of options. We allocate roughly $\$ 10,000.00$ to trade on each of the 30 securities to each type of investor. The number of shares of each stock would be determined by dividing the total dollar amount to be invested by the closing stock price on the day a position would be taken on that stock. If the number comes out as a fraction, we round it to the nearest whole number. In the case of a short sale, the dollar amount allocated is used as collateral for the short sale. Since the time period is only three weeks, no interest income is allowed to be earned on the collateral amount. In the case of portfolios with derivatives, since options cannot be written on fraction of shares, we round total number of shares to the nearest hundred so that a full option contract can be written on the stock holdings.

Table 3: Percent Rates Of Return For Informed And Uninformed

Investors For The Stock Only Strategy For May 1999

\begin{tabular}{|c|c|c|c|c|c|c|c|}
\hline Stock Symbol & $\boldsymbol{P}_{T i}$ & $\boldsymbol{P}_{t i}{ }^{Z}$ & $P_{t i}$ & $\boldsymbol{P}_{t i}^{f}$ & $\begin{array}{l}\text { Strategy for } \\
\text { Informed } \\
\text { Investors }\end{array}$ & $\begin{array}{l}\text { Return to } \\
\text { Informed } \\
\text { Investors }\end{array}$ & $\begin{array}{c}\text { Return to } \\
\text { Uninformed } \\
\text { Investor }\end{array}$ \\
\hline $\mathrm{ABX}$ & 17.88 & 18.90 & 20.25 & 17.17 & Short & 11.70 & -11.70 \\
\hline ALTR & 72.00 & 70.05 & 72.75 & 72.05 & Short & 1.03 & -1.03 \\
\hline AMAT & 59.56 & 61.78 & 53.63 & 56.03 & Long & 11.06 & 11.06 \\
\hline AMGN & 61.25 & 67.97 & 61.44 & 63.65 & Long & -0.31 & -0.31 \\
\hline AMR & 66.38 & 61.69 & 69.81 & 66.87 & Short & 4.91 & -4.91 \\
\hline ASND & 93.75 & 85.65 & 96.25 & 93.81 & Short & 2.60 & -2.60 \\
\hline $\mathrm{C}$ & 67.82 & 68.60 & 72.50 & 71.32 & Short & 6.46 & -6.46 \\
\hline CMB & 78.94 & 76.78 & 82.50 & 81.17 & Short & 4.32 & -4.32 \\
\hline COMS & 29.44 & 25.07 & 26.12 & 23.48 & Short & -12.71 & 12.71 \\
\hline CPQ & 25.06 & 25.56 & 22.31 & 21.11 & Short & -12.33 & 12.33 \\
\hline $\mathrm{CSCO}$ & 113.25 & 109.10 & 114.00 & 114.72 & Long & -0.66 & -0.66 \\
\hline CTL & 41.69 & 44.20 & 40.25 & 40.30 & Long & 3.58 & 3.58 \\
\hline DAL & 60.50 & 60.25 & 63.44 & 62.04 & Short & 4.63 & -4.63 \\
\hline $\mathrm{DD}$ & 68.25 & 62.35 & 70.69 & 67.71 & Short & 3.45 & -3.45 \\
\hline DELL & 37.31 & 37.25 & 41.19 & 38.27 & Short & 9.42 & -9.42 \\
\hline DIS & 29.50 & 30.15 & 31.75 & 29.21 & Short & 7.09 & -7.09 \\
\hline GE & 104.13 & 97.25 & 105.38 & 104.39 & Short & 1.19 & -1.19 \\
\hline $\mathrm{KO}$ & 68.00 & 64.50 & 68.06 & 66.77 & Short & 0.09 & -0.09 \\
\hline MCD & 39.88 & 44.10 & 42.38 & 41.70 & Short & 5.90 & -5.90 \\
\hline MO & 39.88 & 41.35 & 35.06 & 35.73 & Long & 13.75 & 13.75 \\
\hline MOT & 86.06 & 79.94 & 80.00 & 80.71 & Long & 7.58 & 7.58 \\
\hline MU & 37.31 & 43.15 & 37.25 & 37.89 & Long & 0.16 & 0.16 \\
\hline ORCL & 25.75 & 26.78 & 27.06 & 24.77 & Short & 4.84 & -4.84 \\
\hline PG & 97.25 & 96.30 & 93.81 & 96.25 & Long & 3.67 & 3.67 \\
\hline S & 48.25 & 49.26 & 46.00 & 46.11 & Long & 4.89 & 4.89 \\
\hline SLB & 61.06 & 54.90 & 63.89 & 60.29 & Short & 4.43 & -4.43 \\
\hline SUNW & 60.19 & 60.99 & 59.82 & 59.89 & Long & 0.62 & 0.62 \\
\hline UTX & 128.25 & 130.51 & 144.88 & 143.67 & Short & 11.48 & -11.48 \\
\hline WCOM & 84.88 & 87.34 & 82.19 & 85.01 & Long & 3.27 & 3.27 \\
\hline WMT & 43.25 & 47.65 & 46.00 & 45.49 & Short & 5.98 & -5.98 \\
\hline Mean Return & & & & & & 3.74 & -0.56 \\
\hline Standard Deviation & & & & & & 5.70 & 6.79 \\
\hline
\end{tabular}




\section{RESULTS AND ANALYSIS}

The comparative performance analysis is conducted for these portfolios for three consecutive option months, May through July 1999. Results for the April $30^{\text {th }}$ trading day are shown in Table 3 for both types of investor using the stocks only strategy. The first column indicates the stock ticker in the sample, while the second column displays the stock closing price on the option maturity date, which is May 21, 1999. The third column shows the option-based price predictor for April $30^{\text {th }}$. The fourth column indicates the stock price on April $30^{\text {th }}$. The fifth column indicates the stock price forecast for the expiration day as given by equation 2 , when coefficients are restricted to be identical across months. The sixth column shows the informed investor's strategy. His choice is to go long or short depending on the forecast price in column 5 and its relation to the contemporaneous stock price in column 4. The last two columns display the percentage rates of return over the 21 day period for the two types of traders, where the percentage rates of return are simply the net profit on each transaction divided by the purchase price of the stock.

The results from Table 3 indicate that the mean percentage return to informed investors is $3.74 \%$, while the mean percentage return to uninformed investors is $-0.56 \%$. For informed investors, the standard deviation of the cross-sectional returns of the stock positions for the month is 5.70\%. For uninformed investors it is $6.79 \%$.

Table 4 provides the mean percentage return for all three months. The first column shows the option expiration month. Open interest is observed 21 days prior to option expiration. The monthly average percentage returns and standard deviations (in parenthesis) for the informed and uninformed investors are shown in columns two and three for the informed investor and columns four and five for the uninformed. Finally, the last column shows the performance of the S\&P 500 index during the same period. Informed investors' overall mean percentage return is $6.88 \%$. Uninformed investors' overall mean percentage return is $6.07 \%$. Both informed and uninformed investors outperform the return on the S\&P 500 market index, which is $1.39 \%$ for the same period.

Table 4: Mean Percent Rates Of Return For Informed And Uninformed Investors For Stock Only Strategy

\begin{tabular}{lccccc}
\hline Option Expiration Month & \multicolumn{2}{c}{$\begin{array}{c}\text { Informed } \\
\text { Investor }\end{array}$} & \multicolumn{2}{c}{$\begin{array}{c}\text { Uninformed } \\
\text { Investor }\end{array}$} & $\begin{array}{c}\text { S\&P 500 } \\
\text { Index }\end{array}$ \\
\hline May & 3.74 & $(5.70)$ & $-0.56 \quad(6.79)$ & -2.25 \\
June & 5.55 & $(22.95)$ & $10.70 \quad(19.95)$ & 2.34 \\
July & 11.36 & $(17.78)$ & $8.08 \quad(19.09)$ & 4.09 \\
Mean For All Three Expiration Months & \multicolumn{2}{c}{6.88} & \multicolumn{2}{c}{6.07} & 1.39 \\
\hline
\end{tabular}

(Values in parenthesis are standard deviation)

The comparative performance analyses for the strategies which use options are shown for the April $30^{\text {th }}$ trading day in Table 5. For each stock, column 6 indicates the strategy for the informed investor. Both informed and uninformed investors invest in a covered call, but the uninformed investor always uses the out-of-the-money strike price nearest to the contemporaneous stock price. If the expiration day stock price forecast is above the stock price, the informed investors use the out-of-the-money strike price nearest to the forecast price in the covered call strategy. If the forecast is below the stock price, the informed investor will select the strike price nearest to the forecast price and further, add a purchased put with a strike price nearest to the contemporaneous stock price. In this last case, the moneyness of both the call and the put does not come into consideration.

Consider the first stock in Table 5: Barrick Gold (ABX). The forecast price of $\$ 17.17$ is less than the contemporaneous stock price of $\$ 20.25$. The informed investor will write a covered call, using the $\$ 17.50$ strike price and also buy a put with strike price $\$ 20$. The uninformed investor will write a covered call with strike price $\$ 22.50$, although this is not shown in the table. Because the stock price at expiration is $\$ 17.88$, the informed investor's portfolio outperforms the uninformed in this particular instance.

The last two columns in Table 5 display the percentage rates of return over the 21 day period for the two types of investor. The results from Table 5 indicate that the mean percentage return to informed investors is $4.52 \%$, 
while the mean percentage return to uninformed investors is $0.81 \%$. For informed investors, the standard deviation of the cross-sectional returns of the stock positions for the month is $4.37 \%$. For uninformed investors it is $7.32 \%$.

Table 6 provides the summary results for all three months. Informed investors' mean overall percentage return is $8.38 \%$, which outperforms uninformed investors' mean percentage return of $5.88 \%$. For every month, the mean return for informed investors is greater and the standard deviation is less than the same measures for uninformed investors.

In the Table 7, we present the summary statistics of all signals generated from our option-based forecasted stock prices for three consecutive months and their level of accuracy. In the month of May 1999, out of 12 up signals, 10 are accurate, and out of 18 down signals, 16 are accurate. In total, 26 out of 30 signals are accurate. In the month of June, out of 20 up signals, 16 are accurate and out of 10 down signals, 3 of them are accurate. In total, there are 19 signals out of 30 that are accurate in this month. The down signals are mostly inaccurate in this month. Finally, in the month of July 1999, out of 15 up signals 12 of them are accurate and 8 of the down signals are accurate. In this month, in total, 20 out of 30 signals are accurate. Overall, 65 out of 90 signals turn out to be accurate in all three months.

Table 5: Percent Rates Of Return For Informed And Uninformed Investors For The Stock With Options Strategy For May 1999

\begin{tabular}{|c|c|c|c|c|c|c|c|}
\hline $\begin{array}{l}\text { Stock } \\
\text { Symbol }\end{array}$ & $\boldsymbol{P}_{T i}$ & $P_{t i}{ }^{Z}$ & $P_{t i}$ & $P_{t i}^{f}$ & $\begin{array}{c}\text { Strategy for } \\
\text { Informed } \\
\text { Investors }\end{array}$ & $\begin{array}{l}\text { Return to } \\
\text { Informed } \\
\text { Investors }\end{array}$ & $\begin{array}{c}\text { Return to } \\
\text { Uninformed } \\
\text { Investors }\end{array}$ \\
\hline $\mathrm{ABX}$ & 17.88 & 18.90 & 20.25 & 17.17 & $\mathrm{X}^{\mathrm{C}}=17.5 \mathrm{X}^{\mathrm{P}}=20$ & 6.16 & -12.53 \\
\hline ALTR & 72.00 & 70.05 & 72.25 & 72.05 & $\mathrm{X}^{\mathrm{C}}=72.5 \mathrm{X}^{\mathrm{P}}=72.5$ & 0.46 & 1.46 \\
\hline AMAT & 59.56 & 58.24 & 53.63 & 56.03 & $X^{C}=60$ & 7.66 & 10.28 \\
\hline AMGN & 61.25 & 67.97 & 61.44 & 63.65 & $X^{C}=65$ & 0.49 & 2.42 \\
\hline AMR & 66.38 & 61.69 & 69.81 & 66.87 & $\mathrm{X}^{\mathrm{C}}=70 \quad \mathrm{X}^{\mathrm{P}}=70$ & 4.35 & -4.01 \\
\hline ASND & 93.75 & 85.65 & 96.25 & 93.81 & $X^{C}=95 \quad X^{P}=95$ & 5.25 & -1.45 \\
\hline $\mathrm{C}$ & 67.82 & 68.60 & 72.50 & 71.32 & $\mathrm{X}^{\mathrm{C}}=70 \quad \mathrm{X}^{\mathrm{P}}=75$ & 4.00 & -5.97 \\
\hline CMB & 78.94 & 76.78 & 82.50 & 81.17 & $\mathrm{X}^{\mathrm{C}}=85 \quad \mathrm{X}^{\mathrm{P}}=85$ & 2.98 & -2.01 \\
\hline COMS & 29.44 & 25.07 & 26.12 & 23.48 & $X^{C}=25 \quad X^{P}=27.5$ & -4.30 & 16.01 \\
\hline CPQ & 25.06 & 25.56 & 22.31 & 21.11 & $\mathrm{X}^{\mathrm{C}}=25 \quad \mathrm{X}^{\mathrm{P}}=25$ & -4.78 & 17.04 \\
\hline CSCO & 113.25 & 109.10 & 114.06 & 114.73 & $X^{C}=115$ & -0.35 & -0.35 \\
\hline CTL & 41.69 & 44.20 & 40.25 & 40.30 & $\mathrm{X}^{\mathrm{C}}=42.5$ & 3.52 & 3.52 \\
\hline DAL & 60.50 & 60.25 & 63.44 & 62.04 & $X^{C}=65 \quad X^{P}=65$ & 5.87 & -3.57 \\
\hline $\mathrm{DD}$ & 68.25 & 62.35 & 70.69 & 67.71 & $X^{C}=65 \quad X^{P}=70$ & 3.28 & -1.98 \\
\hline DELL & 37.31 & 41.56 & 41.19 & 38.27 & $\mathrm{X}^{\mathrm{C}}=35 \quad \mathrm{X}^{\mathrm{P}}=45$ & 10.94 & -6.79 \\
\hline DIS & 29.50 & 32.86 & 31.75 & 29.21 & $\mathrm{X}^{\mathrm{C}}=27.5 \mathrm{X}^{\mathrm{P}}=30$ & 1.67 & -7.47 \\
\hline GE & 104.13 & 97.25 & 105.38 & 104.39 & $\mathrm{X}^{\mathrm{C}}=105 \mathrm{X}^{\mathrm{P}}=105$ & 3.27 & 1.27 \\
\hline $\mathrm{KO}$ & 68.00 & 64.50 & 68.06 & 66.77 & $X^{C}=65 \quad X^{P}=65$ & 1.78 & 0.07 \\
\hline MCD & 39.88 & 44.10 & 42.38 & 41.70 & $\mathrm{X}^{\mathrm{C}}=42.5 \mathrm{X}^{\mathrm{P}}=42.5$ & 5.67 & -5.96 \\
\hline MO & 39.88 & 41.35 & 35.06 & 35.76 & $\mathrm{X}^{\mathrm{C}}=37.5$ & 10.39 & 10.39 \\
\hline MOT & 86.06 & 79.94 & 80.00 & 80.71 & $\mathrm{X}^{\mathrm{C}}=85$ & 12.73 & 12.73 \\
\hline MU & 37.31 & 43.15 & 37.25 & 37.89 & $\mathrm{X}^{\mathrm{C}}=40$ & 0.83 & 0.83 \\
\hline ORCL & 25.75 & 26.78 & 27.06 & 24.77 & $\mathrm{X}^{\mathrm{C}}=25 \mathrm{X}^{\mathrm{P}}=27.5$ & 4.03 & -5.33 \\
\hline PG & 97.25 & 96.30 & 93.81 & 96.71 & $\mathrm{X}^{\mathrm{C}}=100$ & 8.57 & 3.65 \\
\hline S & 48.25 & 49.26 & 46.00 & 46.11 & $\mathrm{X}^{\mathrm{C}}=50$ & 13.23 & 13.23 \\
\hline SLB & 61.06 & 54.90 & 63.89 & 58.89 & $X^{C}=60 X^{P}=65$ & 3.46 & -4.12 \\
\hline SUNW & 60.19 & 60.99 & 59.82 & 59.89 & $X^{C}=60$ & 2.30 & 0.59 \\
\hline UTX & 128.25 & 130.51 & 144.88 & 143.67 & $\mathrm{X}^{\mathrm{C}}=145 \mathrm{X}^{\mathrm{P}}=145$ & 11.27 & -5.35 \\
\hline WCOM & 84.88 & 87.34 & 82.19 & 85.01 & $\mathrm{X}^{\mathrm{C}}=85$ & 3.02 & 3.60 \\
\hline WMT & 43.25 & 47.65 & 46.00 & 45.49 & $X^{C}=45 X^{P}=45$ & 7.84 & -6.01 \\
\hline \multicolumn{6}{|c|}{ Mean Return } & 4.52 & 0.81 \\
\hline \multicolumn{6}{|c|}{ Standard Deviation } & 4.37 & 7.32 \\
\hline
\end{tabular}


Table 6: Mean Percent Rates Of Return For Informed And Uninformed Investors For The Stock With Options Strategy

\begin{tabular}{|c|c|c|c|}
\hline Option Expiration Month & $\begin{array}{c}\text { Informed } \\
\text { Investor }\end{array}$ & $\begin{array}{c}\text { Uninformed } \\
\text { Investor }\end{array}$ & $\begin{array}{c}\text { S\&P 500 } \\
\text { Index }\end{array}$ \\
\hline May & $4.52 \quad(4.37)$ & $0.81 \quad(7.32)$ & -2.25 \\
\hline June & $9.04 \quad(9.81)$ & $(14.79)$ & 2.34 \\
\hline July & $11.58 \quad(11.82)$ & $(13.63)$ & 4.09 \\
\hline Mean For All Three Expiration Months & 8.38 & 5.88 & 1.39 \\
\hline
\end{tabular}

(Values in parenthesis are standard deviation.)

Table 7: Summary Statistics Of All Signals

\begin{tabular}{|c|c|c|c|}
\hline & May & June & July \\
\hline Number of Up Signals per Month & $12(40 \%)$ & $20(67 \%)$ & $15(50 \%)$ \\
\hline Number of Accurate Up Signals per Month & $10(83 \%)$ & $16(80 \%)$ & $12(80 \%)$ \\
\hline Number of Down Signals per Month & $18(60 \%)$ & $10(33 \%)$ & $15(50 \%)$ \\
\hline Number of Accurate Down Signals per Month & $16(89 \%)$ & $3(30 \%)$ & $8(53 \%)$ \\
\hline Total Signals per Month & 30 & 30 & 30 \\
\hline Number of Accurate Signals (Up or Down) per Month & $26(87 \%)$ & $19(63 \%)$ & $20(67 \%)$ \\
\hline Number of Accurate Signals for All Three Months: & $65(72 \%)$ & & \\
\hline
\end{tabular}

(Values in parentheses represent percentages)

\section{CONCLUDING REMARKS}

In this paper we test the performance of strategies using stock price forecasts based on option open interest data. We propose a measure, which we call the predictor, which preserves the information captured by the distribution of open interest across available strike prices. The predictor is a significant variable in the forecast model. We use a three month sample to estimate coefficients for the model, and a subsequent three month sample to test the benefit of using the forecasts to design investment strategies. A stock only strategy and a stock with options strategy are used by both informed and uninformed investors.

For the stock only strategy, the informed investors outperformed the uninformed overall, but not for one of the option expiration months. For the stock with options strategy, the informed investors outperformed both overall and in every individual option expiration month. The cross-sectional standard deviation for stock positions was less in every month for the informed investors compared to the uninformed. The informed investors using an optionbased strategy also outperform the informed investors' stock only strategy, both overall and month by month. The standard deviation of the cross-sectional returns for the option-based strategy was also smaller than the stock only strategy for every month. This was clearly the best strategy.

It seems that not all publicly available information is fully reflected in the security price. Our findings also suggest that covered call writers can benefit when they can select appropriate strikes prices of the derivative securities based on open interest information.

\section{AUTHOR INFORMATION}

Rafiqul Bhuyan (aka Rafiqul Bhuyan Rafiq) is Associate Professor of Finance at California State University San Bernardino. Dr. Bhuyan's current research interests include volatility forecasting, information discovery, and empirical options. He has published in Derivatives Use, Trading, and Regulations, the Journal of Emerging Markets, Applied Financial Economics, Journal of Financial and Economic Practices, and the Journal of Business and Economics Research. Professor Bhuyan earned his M. S. degree from the University of Illinois at UrbanaChampaign and his Ph.D. from Concordia University, Canada.

Steven Freund is Assistant Professor of Finance in the College of Management at the University of Massachusetts Lowell. Dr. Freund's current research interests are in the areas of mergers and acquisitions, security markets, and 
financial derivatives. He has published articles in the Journal of Banking and Finance, Journal of Derivatives, Quarterly Review of Economics and Finance, Journal of Financial Research, Financial Management, and the Journal of Emerging Markets. Professor Freund holds a B.S. in Management Engineering from Rensselaer Polytechnic Institute, an M.B.A. from the University of Connecticut, and a Ph.D. from New York University's Stern School of Business.

Yuxing Yan is a Research Service Director at the Wharton Research Data Services (WRDS), Wharton School, University of Pennsylvania. Prior to joining WRDS in 2003, he taught at McGill University, Wilfred Laurier University, and Nanyang Technological University. Dr. Yan's research interests include portfolio theory, information discovery, constructing unbiased market indices, and market microstructure. He has published articles in the Journal of Empirical Finance, Journal of Banking and Finance, Pacific Basin Finance Journal, International Review of Economics and Finance, and the Annals of Operations Research. Dr. Yan graduated from McGill University with a Ph.D. in Finance.

\section{REFERENCES}

1. Anthony, J., 1988, “The Interrelation of Stock and Options Market Trading-Volume Data," Journal of Finance 43, pp. 949-964.

2. Bhuyan, R. and M. Chaudhury, 2003, "Trading on the Information Content of Open Interest: Evidence from the US Equity Options Market," Derivative Use, Trading \& Regulation, 11 (1), pp. 16-36.

3. Black, F. and M. Scholes, 1973, "The Pricing of Options and Corporate Liabilities," Journal of Political Economy 81 (3), pp. 637-654.

4. Blume, L., D. Easley, and M. O'Hara, 1994, "Market statistics and technical analysis: Role of volume," Journal of Finance 49, pp. 153-182.

5. Chiras, D. P. and S. Manaster, 1978, "The Information Content of Option Prices and a Test of Market Efficiency," Journal of Financial Economics, 6 (2/3), pp. 213-234.

6. Easley, D., M. O'Hara, and P. S. Srinivas, 1998, "Option Volume and Stock Prices: Evidence on Where Informed Traders Trade," Journal of Finance, 2, pp. 431-465.

7. Manaster, S. and R. J. Rendleman, 1982, "Option Prices as Predictors of Equilibrium Stock Prices", Journal of Finance, 37, pp. 1043-1057.

8. Merton, R. C., M. Scholes, and M. Gladstein, 1978, "The Returns and Risk of Alternative Call Option Portfolio Investment Strategies", Journal of Business, 51, pp. 183-242.

9. Newey W.K. and K. W. West, 1987, "Hypothesis Testing with Efficient Method of Moments Estimation," International Economics Review, pp. 777-787. 
Journal of Business \& Economics Research-September, 2009 Volume 7, Number 9

NOTES 